\title{
ARTIGOS
}

Submetido em 04.09.2012. Aprovado em 05.03.2013

Avaliado pelo sistema double blind review. Editora Científica: Fernanda Finotti Cordeiro Perobelli

http://dx.doi.org/10.1590/So034-759020140506

\section{CESSÃO DE CRÉDITO E RESTRIÇÃO DE CAPITAL: UM ESTUDO COM BANCOS BRASILEIROS}

\author{
Loan sales and capital constraint: a study on Brazilian banks \\ Cesión de crédito y restricción de capital: un estudio con bancos brasileños
}

\begin{abstract}
RESUMO
Este estudo investiga a relação entre restrição de capital e as operações de cessão de crédito realizadas pelos bancos brasileiros. O período de análise, compreendido entre junho de 2004 e junho de 2009 - em que as cessões de crédito aumentaram em quase 20 vezes, ante um crescimento de $162 \%$ no volume de crédito - inclui a crise financeira de 2008/2009, choque exógeno ao sistema financeiro brasileiro, durante o qual instituições financeiras enfrentaram dificuldades por causa da diminuição na captação por meio de depósitos livres e interbancários. Isso permite, também, verificar se os efeitos da restrição de capital sobre a cessão se exacerbam diante de crises financeiras. Os resultados observados indicam que um aumento na restrição de capital - próprio e de terceiros - está relacionado à expansão das operações de cessão de crédito realizadas pelos bancos brasileiros.
\end{abstract}

PALAVRAS-CHAVE | Cessão, coobrigação, crédito, restrição de capital, liquidez bancária.

\begin{abstract}
This study investigates the relation between capital restriction and credit assignment operations carried out by Brazilian banks. The analysis period, between June 2004 and June 2009 - when credit assignments increased almost by 20 times, in face of a $162 \%$ growth in credit volume - includes the 2008/2009 financial crisis, an exogenous shock to Brazilian financial system during which financial institutions faced difficulties due to the reduction in fund raising by means of free and inter-bank deposits. This also allows observing whether capital restriction effects on credit assignment are higher during financial crises. The results indicate that an increase in capital restriction - both equity and debt' - is related to the expansion of credit assignment operations of Brazilian banks.
\end{abstract}

KEY-WORDS / Loan sales, co-obligation, credit, capital constraint, bank liquidity.

\section{FERNANDA VIEIRA FERNANDES RIBEIRO}

fernanda.vfribeiro@gmail.com Analista do Banco Central do Brasil São Paulo - SP, Brasil

\section{RAFAEL FELIPE SCHIOZER}

rafael.schiozer@fgv.br

Professor da Escola de

Administração de Empresas de São

Paulo, Fundação Getulio Vargas -

São Paulo - SP, Brasil

\section{RESUMEN}

Este estudio investiga la relación entre restricción de capital y las operaciones de cesión de crédito realizadas por los bancos brasileños. El periodo de análisis, comprendido entre junio de 2004 y junio de 2009 - periodo donde las cesiones de crédito aumentaron casi 20 veces, frente a un crecimiento de $162 \%$ en volumen de crédito - incluye la crisis financiera de 2008/2009, choque exógeno al sistema financiero brasileño, durante el cual las instituciones financieras enfrentaron dificultades causadas por la disminución en la captación por medio de depósitos libres e interbancarios. Esto permite, también, verificar si los efectos de la restricción de capital sobre la cesión se exacerban frente a crisis financieras. Los resultados observados indican que un aumento en la restricción de capital - propio y de terceros - está relacionado a la expansión de las operaciones de cesión de crédito realizadas por los bancos brasileños.

PALABRAS CLAVE / Cesión, coobligación, crédito, restricción de capital, liquidez de los bancos. 


\section{INTRODUÇÃO}

Embora haja diversos estudos internacionais realizados no campo da cessão de crédito, a recente crise financeira e os eventos envolvendo bancos de pequeno e médio portes no Brasil transparecem a necessidade de retomada quanto ao entendimento do tema.

A cessão de crédito tem sido abordada na literatura internacional como uma alternativa de financiamento para bancos com restrição de capital. 0 volume de cessão de crédito no Brasil aumentou quase 20 vezes entre 2004 e 2009 , ao passo que as operações de crédito aumentaram cerca de 2,5 vezes. Ainda assim, as investigações sobre esse tema no Brasil são praticamente inexistentes. Tendo isso em vista, o objetivo principal deste estudo é verificar se há relação positiva entre restrição de capital e as operações de cessão de crédito realizadas pelos bancos brasileiros. Por se tratar de um estudo seminal no Brasil, foi realizado um levantamento de normativos que disciplinam a cessão de crédito no País. 0 período de análise, compreendido entre junho de 2004 e junho de 2009 , inclui o impacto da recente crise financeira, período relevante tendo em vista a dificuldade enfrentada pelos bancos menores diante da redução da captação por meio de depósitos e dos empréstimos interbancários. A ocorrência de uma crise financeira, exógena ao sistema bancário brasileiro (uma vez que os bancos brasileiros não tinham exposição aos empréstimos subprime que causaram a crise), permite, do ponto de vista empírico, a identificação mais clara de causalidade entre restrição de capital e cessão de crédito. Mais especificamente, o trabalho testa duas hipóteses: i) se bancos com restrição de capital cedem mais; e ii) se os efeitos da restrição de capital sobre a cessão se exacerbam diante de crises financeiras.

Diversos estudos foram realizados abordando a securitização como uma das razões para a recente crise financeira (Farruggio, Michalak, \& Uhde, 2011; Loutskina, 2011; Martín-Oliver \& Saurina, 2007; Panetta \& Pozzolo, 2009). Este artigo busca na cessão de crédito a contribuição ao debate e, em particular, busca a relação entre tais operações e restrição de capital, próprio e de terceiros.

O estudo contribui com a literatura sobre o tema, na medida em que está inserido em um ambiente institucional/legal distinto dos trabalhos anteriores e considera o período da recente crise financeira. Foram abordados aspectos relacionados às peculiaridades brasileiras, considerando tanto operações de cessão com coobrigação quanto sem coobrigação, buscandose explicações distintas para cada modalidade.

Os resultados obtidos indicam a existência de relação positiva entre restrição de capital e as operações de cessão de crédito nos bancos brasileiros. Instituições menos capitalizadas cedem em maior volume. Além disso, a relação entre as modalidades de cessão e a proporção dos ativos financiados por depósitos é distinta: uma redução no capital - tanto nos depósitos quanto no capital regulatório (índice de Basileia) - está relacionada a um aumento nas operações sem coobrigação, com menor efeito nas operações com coobrigação. Observouse, ainda, que há pouca ou nenhuma relação entre a cessão de crédito e o tamanho da instituição financeira.

Este artigo está estruturado em cinco seções: a primeira trata da revisão da literatura, abrangendo também a normatização vigente no País; a segunda apresenta a amostra e a estatística descritiva, incluindo um panorama sobre a evolução das cessões no Brasil; a terceira seção trata da metodologia adotada; a quarta apresenta os resultados obtidos; e a quinta, a conclusão.

\section{REVISÃO BIBLIOGRÁFICA}

Cessão de crédito é a venda de participação ou da totalidade de um empréstimo originado por um agente financeiro (Greenbaum \& Thakor, 1987). Ao explicarem os motivos para a expansão do mercado de cessões, Gorton \& Pennacchi (1995) afirmam que um banco pode financiar seus empréstimos internamente, por meio de depósitos, ou por meio de recursos obtidos com a venda de sua carteira. 0 fato de não ter sido registrada quantidade relevante de cessões até o final da década de 1970 sugere que os custos internos de financiamento eram inferiores aos custos de financiamento da venda de carteira. A elevação na concorrência quanto aos depósitos gera, entretanto, um aumento nos custos de financiamento interno de determinados bancos, podendo resultar na elevação das cessões. A cessão de crédito permite que alguns bancos se financiem a um custo menor em comparação a depósitos tradicionais ou emissão de ações, pois os recursos oriundos das cessões podem evitar custos associados aos depósitos compulsórios e exigibilidade de capital pelo regulador (Pennacchi, 1988).

Tendo em vista a elevação da popularidade da venda de carteiras, Pennacchi (1988) sugere que o mercado de intermediação bancária estaria sofrendo uma alteração fundamental: os bancos, ao venderem suas carteiras, caracterizam-se mais como originadores e distribuidores de empréstimos do que instituições que os detêm como ativos até então não transacionáveis, conforme também mencionaram Greenbaum \& Thakor (1987). Esse fato gera a perda de duas funções típicas das instituições financeiras: provedor de liquidez e monitoramento (Diamond \& Dybvig, 1983). Martín-Oliver \& Saurina (2007) sugerem 
que a principal razão para a cessão de crédito é a necessidade de liquidez e que a expansão do crédito e o menor financiamento interbancário aumentam a probabilidade de realização de tais operações.

As cessões permitem, ainda, que os bancos com pouca restrição de capital adquiram ativos lucrativos originados por bancos cujo capital seja insuficiente para suportar o risco adicional incorrido (Carlstrom \& Samolyk, 1995). Além disso, diante de um aumento na demanda por empréstimos, os bancos com restrição de capital são mais propensos a realizar operações de cessão, concluindo que a venda de carteira pode ser uma fonte de financiamento. Outro motivo para a venda de carteiras no mercado secundário seria o de operar com informação privilegiada (Parlour \& Plantin, 2008), uma vez que, por meio de monitoramento, as instituições financeiras obtêm informações privadas sobre as operações e, dessa forma, podem deparar-se com uma oportunidade de investimento, redistribuindo seus recursos.

Cantor e Demsetz (1993) afirmam que o aumento do estresse financeiro em bancos pode ter reforçado os incentivos à transferência de empréstimos contabilizados em seus balanços a outros investidores com menores custos de financiamento. Uma forma apresentada de mensuração do crescimento do crédito é por meio de empréstimos que não constam em seus balanços, devido à venda direta de crédito ou emissão de títulos lastreados. O fato de os ativos serem transferidos e deixarem de pertencer ao balanço da instituição originadora gera menos incentivos ao monitoramento desses empréstimos por parte do originador (Cabiles, 2011; Pennacchi, 1988) e faz com que a carteira a ser vendida torne-se questionável e menos atraente aos investidores. Fernandez, Valverde \& Rosen (2011) confirmam a relevância tanto do moral hazard quanto da seleção adversa, argumentando que a venda de carteiras abriu espaço para a crise financeira de $2008 / 2009$.

Estudando instituições financeiras italianas, Affinito \& Tagliaferri (2010) observaram que as instituições menos capitalizadas, menos rentáveis, menos líquidas e sobrecarregadas com créditos de baixa qualidade são mais propensas a vender suas carteiras, além de venderem em maior quantidade e mais cedo que seus pares. Utilizando dados de todos os bancos do País entre 2000 e 2006, foram rodados modelos Probit, Logit e três modelos Tobit, buscando verificar uma dupla decisão: o fato de ceder ou não ceder, e a quantidade cedida.

Pereira e Saito (2012) investigaram os determinantes da manutenção de capital acima do mínimo requerido pelo regulador no Brasil, denominado buffer. Observaram que requerimentos de capital influenciam a gestão de capital nos bancos e que o monitoramento por parte da supervisão bancária impacta positivamente os índices de solvência, principalmente nas instituições menos capitalizadas.

O agravamento da crise financeira provocou uma retração relevante nas linhas externas de financiamento e na captação via mercado de capitais no País (Oliveira, 2009). A postura mais defensiva dos investidores e instituições financeiras gerou dois efeitos: o "empoçamento da liquidez" nos grandes bancos e a retração das concessões de crédito. Diante da elevação nos riscos de crédito e liquidez e da maior assimetria de informação, observaram-se dois outros fenômenos: os bancos passaram a atuar com maior cautela em relação aos empréstimos interbancários; e houve uma fuga de depósitos, principalmente de investidores institucionais, dos bancos de menor para os de maior porte (Oliveira, Schiozer, \& Barros, 2012).

Com o objetivo de prover liquidez, o Banco Central do Brasil [BACEN] (2008) implementou um conjunto de medidas. As principais iniciativas foram realizadas por meio de alterações nas regras do depósito compulsório, como mudanças na remuneração dos recolhimentos e abatimentos sobre valores a recolher quando da negociação de ativos (sejam empréstimos interbancários ou compra/venda de carteiras) entre instituições financeiras.

Considerando o período de análise deste estudo, a venda de carteira permitia que o banco cedente antecipasse integralmente as receitas que seriam auferidas com esses recebíveis e, ao mesmo tempo, realizasse a baixa desses ativos de seu balanço. Dessa forma, ao mesmo tempo que antecipava a receita futura, possuía maior margem quanto aos requerimentos mínimos de capital. Com a vigência da Resolução n. 3·533/2008 (Conselho Monetário Nacional [CMN], 2008), desde janeiro de 2012 (não compreendido no presente estudo), entretanto, caso haja retenção substancial dos riscos e benefícios, a receita não mais poderá ser antecipada integralmente nem poderá haver a baixa de ativos do balanço como até então.

A cessão de crédito no Brasil pode dar-se de duas formas: com coobrigação e sem coobrigação. A primeira caracteriza-se pelo direito de regresso do cessionário contra o cedente em caso de inadimplência da operação, havendo, dessa forma, retenção do risco pelo cedente, com possível impacto negativo sobre o capital. Essa modalidade de cessão tem maior custo de capital em relação à cessão sem coobrigação, pois requer alocação de capital regulatório por parte do cedente em caso de inadimplência. A cessão sem coobrigação é a venda definitiva do ativo, em que o cessionário, por não reter os riscos da operação, não detém o direito de regresso sobre os créditos adquiridos, “liberando" capital regulatório em definitivo. Além de 
ocorrer a baixa dos ativos do balanço, há o reconhecimento da receita integralmente no período.

A cessão sem coobrigação tem, assim, o efeito de "liberar” capital regulatório do banco cedente de maneira definitiva, por isso espera-se que a restrição de capital próprio esteja mais intimamente relacionada às cessões sem coobrigação. Com relação à restrição do capital de terceiros, também se espera que esteja relacionada à cessão de créditos. Não é possível, no entanto, a priori, relacionar a restrição de capital de terceiros a nenhuma das modalidades de cessão.

\section{AMOSTRA E DADOS}

Neste estudo, foi utilizada uma base com dados públicos referentes às operações de cessão de crédito realizadas por instituições financeiras e dados de demonstrações financeiras, entre junho de 2004 e junho de 2009. Os dados constam no site do BACEN: os referentes à cessão, nas seções de Informações Financeiras Trimestrais, e os demais, na seção 50 Maio- res Bancos (que, apesar do nome, inclui todos os conglomerados bancários brasileiros). Para os dados de demonstrações financeiras, foram considerados os Consolidados Bancários I e II, conforme classificação do BACEN. Optou-se por utilizar dados semestrais, pois as demonstrações relativas a junho e dezembro são auditadas, conferindo maior confiabilidade aos dados. Definem-se como períodos de crise o segundo semestre de 2008 (durante o qual ocorreu a falência do banco Lehman Brothers) e o primeiro semestre de 2009 (ao final do qual ocorreu a reunião do $\mathrm{G}_{2} 0$ que decidiu injetar trilhões de dólares na economia), seguindo Aït-Sahalia, Andritzky, Jobst, Novak e Tamirisa (2012).

Com o intuito de eliminar do estudo aqueles bancos cujas atividades de concessão de crédito fossem irrelevantes para seus negócios, foram retiradas da amostra as observações de bancos que apresentaram os $10 \%$ menores valores para a soma de cessão total e operações de crédito sobre ativo total, que totalizavam 118 (bancos-semestre). Com as exclusões, a amostra final contém 1.182 observações. Como testes de robustez, foram considerados os percentuais de $5 \%$ e $15 \%$ (Figura 1).

Figura 1. Número de observações da amostra sob diferentes critérios de exclusão

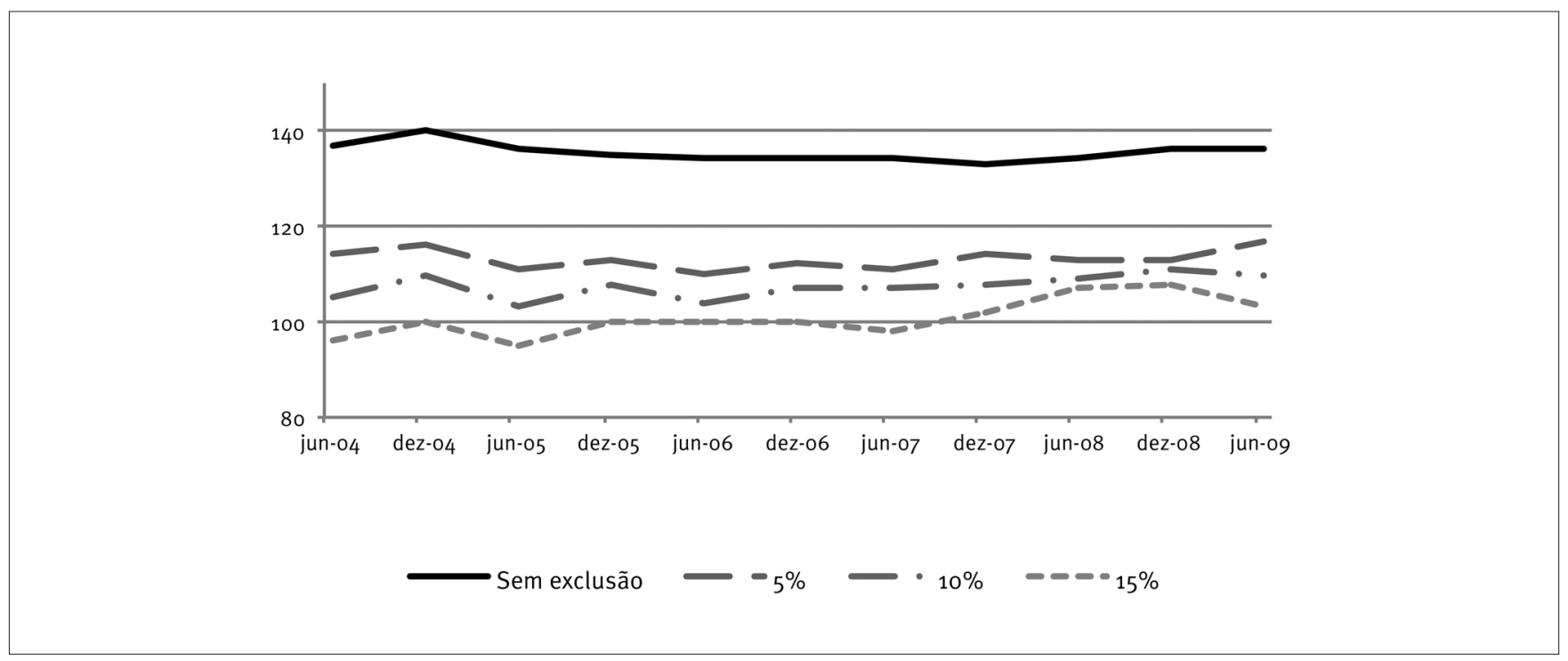

Em relação às variáveis do modelo, foi utilizado como variável dependente o volume de cessão realizada pela instituição em relação ao total da carteira de crédito (operações de crédito e arrendamento mercantil). Embora Affinito and Tagliaferri (2010) tenham considerado o total de ativos como denominador, utilizou-se o total da carteira de crédito, pelo fato de se desejar medir a capacidade de realizar cessões (fluxo de cessão/ estoque de operações de crédito no balanço).

As variáveis independentes são:
- Índice de Basileia: É o valor do patrimônio líquido ajustado em relação ao valor do ativo ponderado pelo risco, utilizado como medida de restrição de capital próprio. Espera-se sinal negativo se as instituições utilizam-se das operações de cessão de crédito para liberar uma parcela de capital (Affinito \& Tagliaferri, 2010). Com o objetivo de mitigar os efeitos extremos de outliers, essa variável foi winsorizada para o quinto e o $95^{\circ}$ percentis. 
- Depósito total/Ativo total: Captura a restrição de capital de terceiros. Espera-se sinal negativo, uma vez que um incremento nos depósitos aumenta a capacidade de o banco manter suas operações de crédito no balanço, não sendo necessário desfazer-se de seus ativos de crédito.

- Tamanho: Utiliza-se o logaritmo natural do ativo total, mitigando o problema de assimetria para a direita da variável. Por um lado, os bancos maiores normalmente concedem crédito de longo prazo, mais propensos a serem cedidos, e têm mais oportunidades de negócio. Por outro lado, os bancos pequenos e médios enfrentam maiores restrições de capital, que podem não estar completamente capturadas nas variáveis acima e, portanto, devem recorrer mais fortemente à cessão. 0 sinal esperado para essa variável é, assim, uma questão empírica.

- Liquidez: É composta pelas três primeiras rubricas do ativo (disponibilidades, aplicações financeiras e títulos e valores mobiliários) sobre ativo total (Schiozer, Oliveira, \& Saito, 2010). Embora não tenham utilizado a variável com essa composição, Affinito and Tagliaferri (2010) encontraram que bancos menos líquidos tendem a ceder mais, e, por isso, espera-se valor negativo.

- Dummy para bancos de grande porte (ABN Amro, Banco do Brasil, Bradesco, CEF, HSBC, Itaú, Santander e Unibanco). Conforme mostram Oliveira, Schiozer, e Barros (no prelo), há um efeito descontínuo do tamanho desses bancos na captação de depósitos, especialmente durante crises. Esses bancos, considerados sistemicamente importantes, normalmente são preferidos pelos depositantes, o que altera a restrição de capital.

Para testes de robustez, foram consideradas, ainda, as seguintes variáveis:

- ROE: 0 retorno sobre patrimônio líquido mede o efeito do crescimento da rentabilidade em relação à realização de operações de cessão de crédito. Espera-se sinal negativo se instituições com lucros menores recorrem às operações de cessão para melhorar sua rentabilidade.

- Capital aberto: Essa dummy assume valor 1 para bancos com capital aberto e zero, caso contrário. Por um lado, o acesso à bolsa de valores pode representar alternativa de funding, o que diminuiria a importância da cessão.
Por outro lado, espera-se que bancos com capital aberto, por serem mais monitorados pelo mercado, tenham menor assimetria de informação sobre seus ativos, melhorando as condições para ceder. A variável foi elaborada tendo por base as datas de abertura de capital das instituições financeiras, obtidas no site da BM\&F-Bovespa.

- Buffer de capital: Tipicamente, os bancos brasileiros possuem índice de Basileia bastante superior ao mínimo regulatório. A restrição de capital próprio pode, assim, estar localizada apenas nos bancos com índice próximo do mínimo regulatório. Seguindo Pereira \& Saito (2012), utilizou-se uma dummy, em que as observações que se situam no primeiro decil da distribuição do índice de Basileia assumem valor 1 (buffer baixo) e as demais observações assumem valor zero; e outra dummy (buffer alto), em que as observações no último decil da distribuição do índice de Basileia assumem valor 1 e as demais, zero.

- Depósito interbancário: 0 menor financiamento interbancário tende a aumentar a probabilidade de realização das operações de cessão de crédito (Martín-Oliver \& Saurina, 2007; Oliveira et al., 2012), esperando-se sinal negativo.

- Interação entre índice de Basileia e depósito total/ativo total: A variável considera, conjuntamente, a restrição de capital próprio e de terceiros. Assim como nas variáveis isoladas, espera-se sinal negativo, supondo que o efeito da restrição de capital sobre as cessões seja intensificado.

\section{Estatísticas descritivas e panorama}

As estatísticas descritivas para jun./2004, dez./2007 e jun./2009 constam na Tabela 1. Enquanto as operações de crédito aumentaram $162,2 \%$ no período, as operações de cessão cresceram 1937,3\%, com maior elevação da modalidade com coobrigação, que registrou alta de $4767,3 \%$; as cessões sem coobrigação aumentaram 895,4\% de jun./2004 para jun./2009. A média do índice de Basileia foi reduzida em 6 pontos percentuais no período.

A distribuição de frequências (Figura 2) mostra que 104 instituições da amostra não realizaram cessões durante o período do estudo e 16 cederam em todos os semestres do período amostral. As medianas de cessão total e cessão com coobrigação desde o primeiro até o último período analisado aumentaram 22,7 e 32,1 vezes, respectivamente (Tabela 2). 
TABELA 1. Estatística descritiva para os períodos: jun./2004, dez./2007 e jun./2009

\begin{tabular}{|c|c|c|c|c|c|c|c|}
\hline \multicolumn{2}{|l|}{$\mathrm{R} \$$ mil } & Depósito Total & $\begin{array}{c}\text { Índice de } \\
\text { Basileia (\%) }\end{array}$ & Operações de & Cessão com & Cessão sem & Cessão Total \\
\hline \multirow{2}{*}{$\frac{\stackrel{す}{Ð}}{\stackrel{.}{\Xi}}$} & Média & 4.867 .861 & 32 & 4.009 .193 & 3.448 & 9.365 & 12.813 \\
\hline & Desvio padrão & 16.040 .101 & 45 & 11.392 .016 & 12.738 & 49.033 & 52.365 \\
\hline \multirow{2}{*}{$\frac{\hat{O}}{\frac{N}{0}}$} & Média & 8.332 .702 & 27 & $7 \cdot 777.118$ & 125.029 & 71.624 & 196.653 \\
\hline & Desvio padrão & 26.694 .213 & 23 & 22.491 .972 & 580.787 & 621.238 & 857.601 \\
\hline \multirow{3}{*}{$\frac{\text { o }}{. \sqsupseteq}$} & Média & 11.334 .047 & 26 & 10.032 .982 & 160.190 & 88.974 & 249.164 \\
\hline & Mediana & 657.321 & 19 & 841.839 & 0 & 0 & 0 \\
\hline & Desvio padrão & 43.171 .352 & 25 & 34.324 .401 & 717.954 & 773.561 & 1.046 .314 \\
\hline
\end{tabular}

\section{TABELA 2. Quartis das instituições que realizaram operações de cessão}

\section{Quartis de cessão total}

\begin{tabular}{|c|c|c|c|c|c|c|c|c|c|c|c|}
\hline & 06.2004 & 12.2004 & 06.2005 & 12.2005 & 06.2006 & 12.2006 & 06.2007 & 12.2007 & 06.2008 & 12.2008 & 06.2009 \\
\hline Mínimo & o & 5 & 5 & 5 & 5 & 0 & 0 & o & o & o & 0 \\
\hline Primeiro & 4.904 & 5.173 & 8.402 & 11.341 & 8.671 & 13.683 & 18.462 & 16.048 & 33.900 & 41.365 & 28.446 \\
\hline Segundo & 8.402 & 20.299 & 23.890 & 28.734 & 29.600 & 56.987 & 59.092 & 59.207 & 151.573 & 151.470 & 199.122 \\
\hline Terceiro & 38.849 & 84.450 & 138.256 & 151.171 & 180.662 & 253.550 & 339.891 & 289.331 & 435.147 & 407.145 & 600.354 \\
\hline Máximo & 396.555 & 865.910 & $3 \cdot 414.710$ & 4.105 .628 & 4.502 .376 & 4.810 .364 & 5.656 .228 & 6.490 .350 & 8.070 .921 & 8.556 .538 & 8.123 .767 \\
\hline
\end{tabular}

\begin{tabular}{|c|c|c|c|c|c|c|c|c|c|c|c|}
\hline & 06.2004 & 12.2004 & 06.2005 & 12.2005 & 06.2006 & 12.2006 & 06.2007 & 12.2007 & 06.2008 & 12.2008 & 06.2009 \\
\hline Mínimo & o & 0 & 0 & 0 & o & o & o & o & o & o & 0 \\
\hline Primeiro & 0 & 0 & 0 & 4 & 1 & o & 0 & 7.602 & 12.482 & 16.665 & 10.198 \\
\hline Segundo & 2.653 & 3.249 & 10.234 & 22.154 & 19.526 & 33.107 & 42.883 & 41.425 & 76.102 & 101.284 & 87.770 \\
\hline Terceiro & 17.476 & 25.691 & 54.032 & 61.113 & 90.742 & 114.313 & 198.701 & 215.253 & 286.137 & 283.273 & 266.504 \\
\hline Máximo & 92.195 & 833.989 & 3.376 .309 & 4.039 .030 & 4.418 .397 & 4.685 .855 & 5.509 .666 & 5.551 .431 & 6.162 .100 & 6.618 .477 & 7.135 .937 \\
\hline \multicolumn{12}{|c|}{ Quartis de cessão sem coobrigação } \\
\hline & 06.2004 & 12.2004 & 06.2005 & 12.2005 & 06.2006 & 12.2006 & 06.2007 & 12.2007 & 06.2008 & 12.2008 & 06.2009 \\
\hline Mínimo & 0 & 0 & 0 & 0 & 0 & 0 & 0 & 0 & 0 & o & 0 \\
\hline Primeiro & o & 0 & 0 & o & o & o & 0 & o & o & o & o \\
\hline Segundo & 3.849 & 4.232 & 8.319 & 5.919 & 774 & 7.050 & 5.258 & 2.041 & 634 & 0 & 33 \\
\hline Terceiro & 8.208 & 15.024 & 35.856 & 17.528 & 19.813 & 35.919 & 22.429 & 16.199 & 24.358 & 27.428 & 31.457 \\
\hline Máximo & 377.402 & 379.413 & 359.239 & 1.064 .637 & 2.273 .422 & 3.550 .313 & 4.688 .230 & 6.449 .956 & 8.037 .290 & 8.528 .667 & 8.101 .165 \\
\hline \multicolumn{12}{|c|}{ Quartis de cessão total/crédito total } \\
\hline & 06.2004 & 12.2004 & 06.2005 & 12.2005 & 06.2006 & 12.2006 & 06.2007 & 12.2007 & 06.2008 & 12.2008 & 06.2009 \\
\hline Mínimo & ०\% & ०\% & ०\% & ०\% & ०\% & ०\% & ०\% & ०\% & ०\% & ०\% & ०\% \\
\hline Primeiro & $1 \%$ & $1 \%$ & $1 \%$ & $1 \%$ & $1 \%$ & $2 \%$ & $2 \%$ & $1 \%$ & $1 \%$ & $2 \%$ & $3 \%$ \\
\hline Segundo & $2 \%$ & $3 \%$ & $3 \%$ & $5 \%$ & $4 \%$ & $9 \%$ & $10 \%$ & $11 \%$ & $14 \%$ & $15 \%$ & $18 \%$ \\
\hline Terceiro & $13 \%$ & $12 \%$ & $27 \%$ & $41 \%$ & $36 \%$ & $50 \%$ & $58 \%$ & $51 \%$ & $54 \%$ & $60 \%$ & $47 \%$ \\
\hline Máximo & $148 \%$ & $126 \%$ & $159 \%$ & $222 \%$ & $247 \%$ & $316 \%$ & $498 \%$ & $382 \%$ & $252 \%$ & $501 \%$ & $543 \%$ \\
\hline
\end{tabular}

Nota: Esta tabela mostra os quartis somente para as instituições que realizaram operações de cessão, de jun./2004 a jun./2009. Considerar R\$ mil como unidade de medida das seguintes variáveis: cessão total, cessão com coobrigação e cessão sem coobrigação. 
Figura 2. Distribuição de frequências

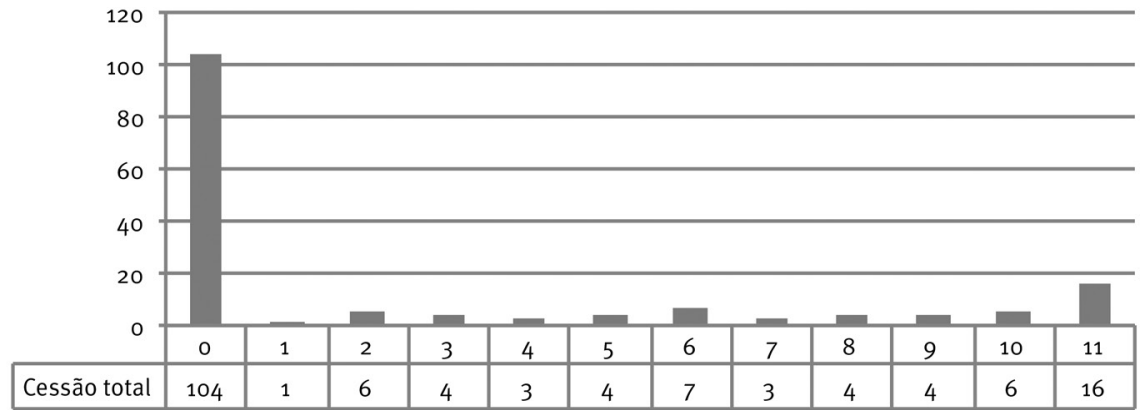

Nota: 0 eixo y apresenta o número de instituições que realizaram operações de cessão, enquanto o eixo x, em quantos semestres realizaram. Dessa forma, o gráfico mostra o número de instituições que realizaram operações de cessão em o, 1, 2, (...) e 11 períodos.

O crescimento das operações de cessão no período superou, em termos relativos, o crescimento do volume de depósitos no período como um todo (Figura 3), em especial a partir da segunda metade de 2007. Analisando as cessões com e sem coobrigação, percebe-se uma elevação em ambas de jun./2004 a dez./2008 e, com exceção de jun./2004, há a predominância das cessões com coobrigação (Figura 4). As instituições de grande porte cederam mais sem coobrigação (Figura 5), cenário oposto ao observado nos bancos pequenos e médios (Figura 6).

\section{Figura 3. Evolução da cessão e depósitos - Todas as instituições}

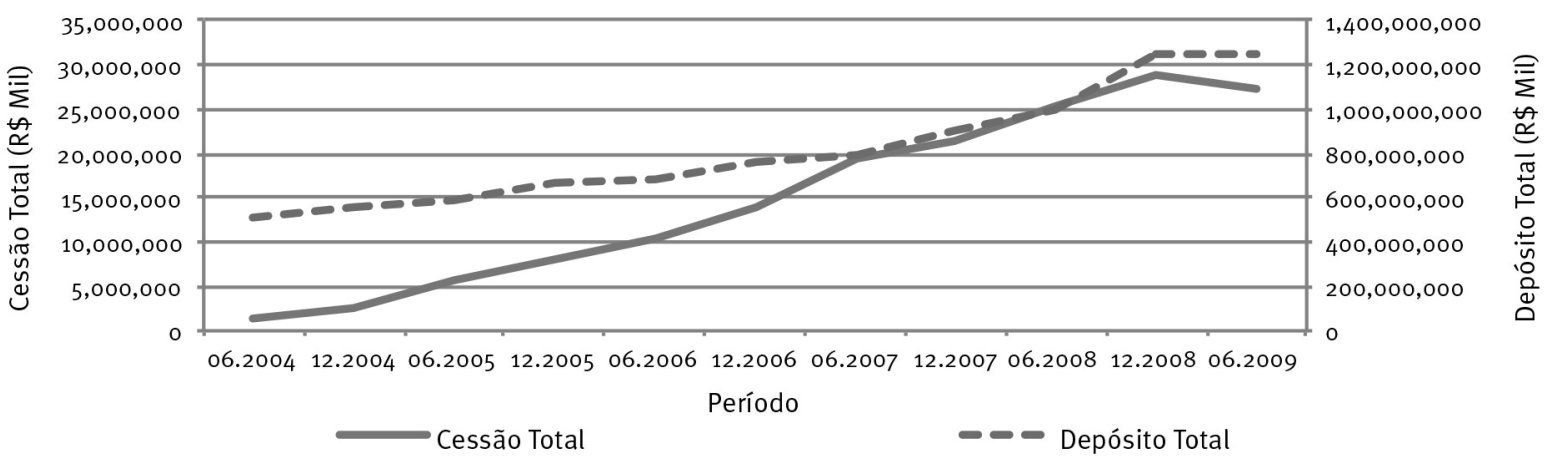

\section{Figura 4. Evolução das cessões com e sem coobrigação - Todas as instituições}

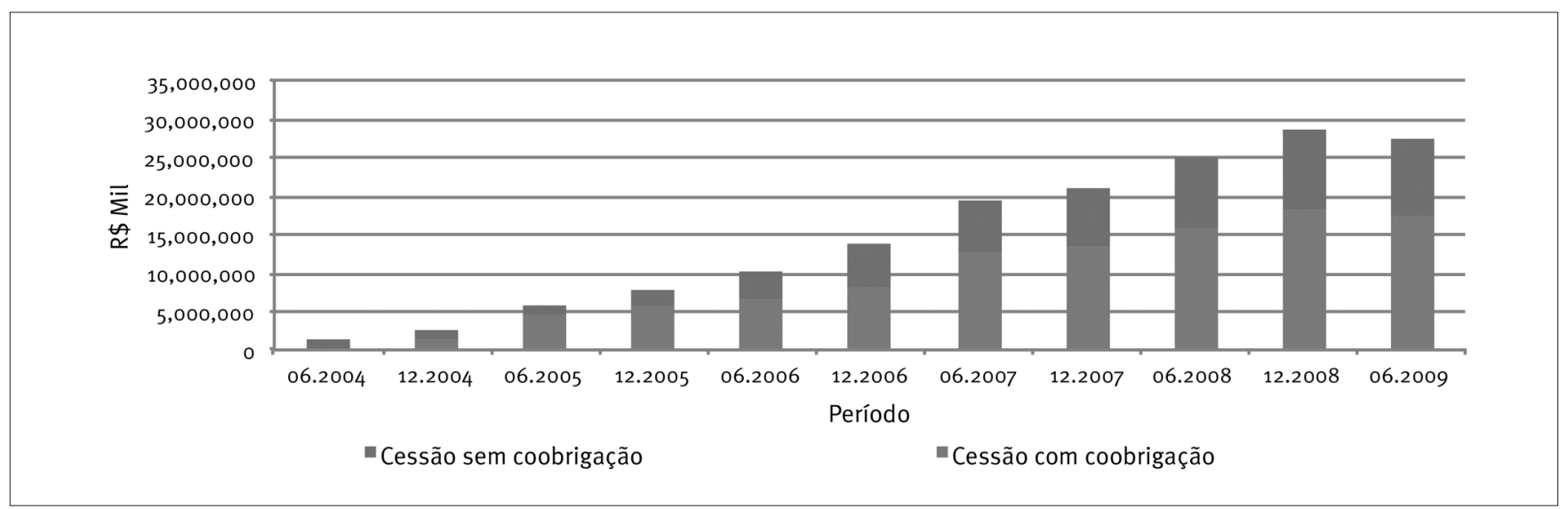


A proporção das cessões com coobrigação nos bancos pequenos e médios é superior à observada nos grandes bancos e manteve-se assim em todo o período, com exceção de jun./2004 (Figura 6). As cessões nessas instituições cresceram aproximadamente $680 \%$ de jun./2004 a dez./2006, quando atingiram cerca de R\$ 9,7 bilhões, e, em jun./2007, aumentaram 47\% em comparação a dez./2006, totalizando R\$14,2 bilhões.

Figura 5. Evolução das cessões com e sem coobrigação - Bancos de grande porte

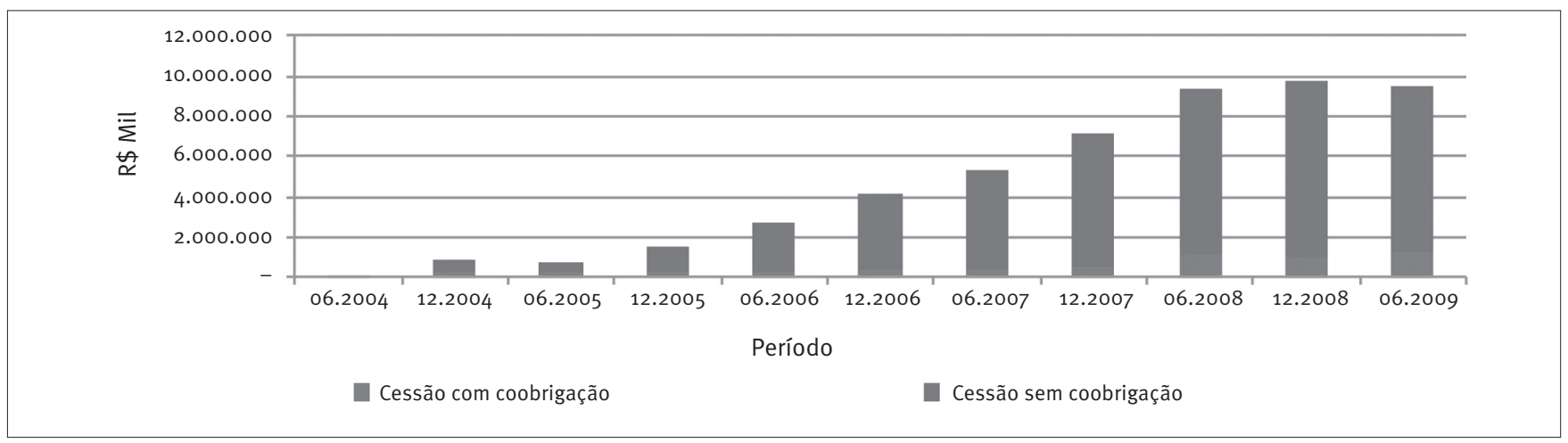

Figura 6. Evolução das cessões com e sem coobrigação - Bancos pequenos e médios

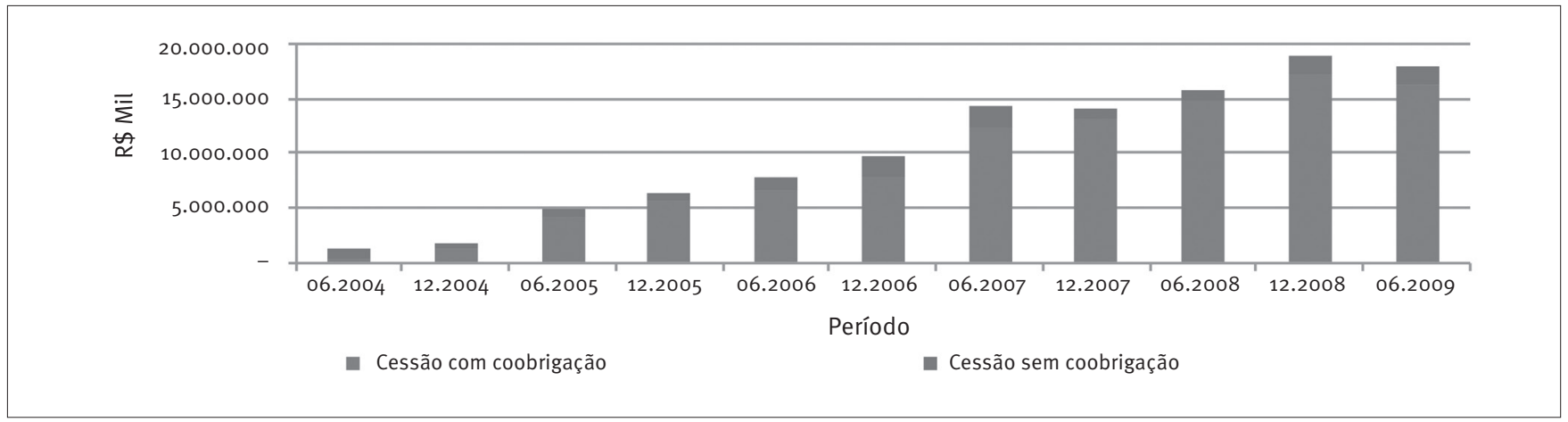

Além disso, a partir de dez./2006, os bancos pequenos e médios elevaram substancialmente as cessões em comparação às operações de crédito (Figura 7). Verifica-se que as cessões de crédito aumentaram cerca de 3,8 vezes nos bancos grandes e 17,2 vezes nos demais, de jun./2004 a jun./2009.

Figura 7. Evolução das cessões em relação à carteira de crédito

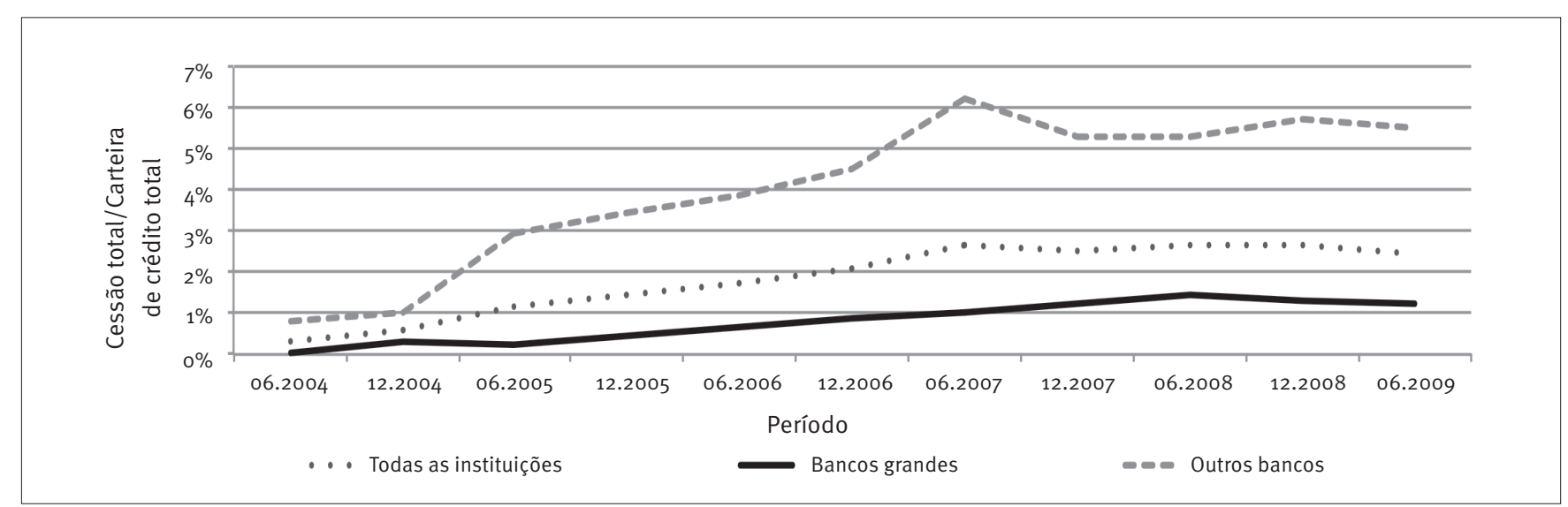




\section{METODOLOGIA}

A teoria apresentada na segunda seção indica uma relação positiva entre cessão de crédito e restrição de capital dos bancos. Além disso, os problemas de restrição de capital são mais severos durante crises financeiras, o que permite formular as seguintes hipóteses:

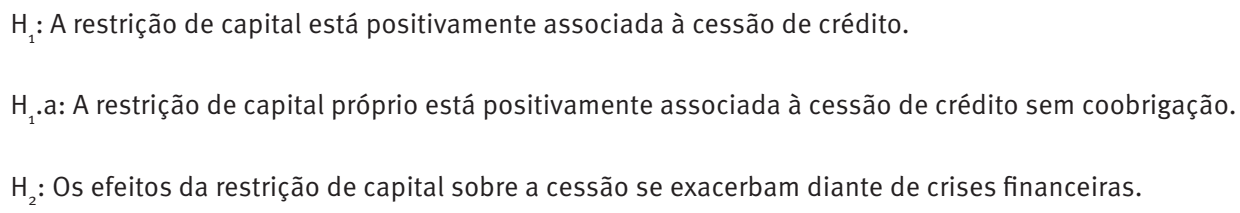

Para testá-las, foi utilizado um modelo Tobit em painel, com e sem variáveis instrumentais, além de testes de robustez, descritos na próxima seção. A equação abaixo foi a utilizada para testar as hipóteses.

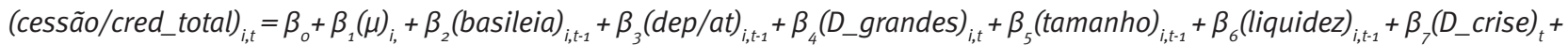

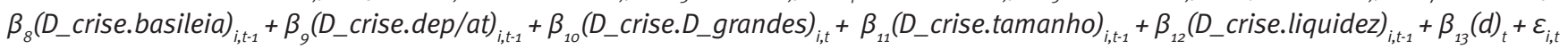
Sendo:

(cessão/cred_total) $_{i, t}$ : volume de cessão sobre a carteira de crédito total no período t;

(cessão/cred_total) $_{i, t-1}:$ volume de cessão sobre a carteira de crédito total no período t-1;

$(\mu)_{i}$ : componente de efeitos aleatórios para cada banco;

(basileia) $_{i, t-1}$ : índice de Basileia no período t-1;

(dep/at $_{i, t-1}$ : depósitos totais sobre ativo total no período t-1;

(D_grandes) : variável binária que assume 1 se a instituição i é considerada "grande” no período t e o, caso contrário;

(tamanho $_{i, t-1}:$ logaritmo natural do ativo total no período $t-1$

(liquidez) $_{i, t-1}$ : índice de liquidez no período t-1;

(D_crise): variável binária que assume 1 na ocorrência da recente crise financeira e zero, caso contrário;

(d): dummies de tempo para cada período, com exceção dos períodos de crise (capturados na variável anterior);

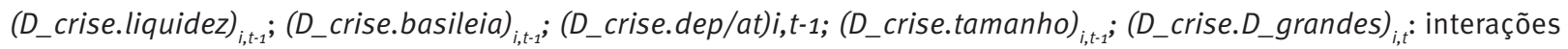
entre a recente crise financeira e as variáveis supramencionadas no período t-1 e, para a última, no período t.

Nesse modelo, o teste para a hipótese $\mathrm{H}_{1}$ faz-se presente pelas variáveis índice de Basileia (restrição de capital próprio) e depósitos sobre ativos (restrição de capital de terceiros); e, para a hipótese $\mathrm{H}$ 2, pela dummy referente à crise e suas interações com as variáveis de restrição de capital.

O modelo utilizado inclui variáveis independentes até então desconsideradas pela literatura, adotadas neste estudo devido às peculiaridades do mercado brasileiro: i) faz-se a diferenciação entre operações de cessão com e sem coobrigação; ii) uma dummy de identificação de bancos de grande porte; e iii) uma dummy para a crise de $2008 / 2009$ e suas interações.
As regressões são rodadas para três variáveis dependentes: o total de operações de cessão de crédito, as cessões com coobrigação e sem coobrigação, separadamente. Adicionalmente, as regressões foram rodadas para uma amostra contendo todos os bancos (doravante chamada de "base total") e também para uma subamostra que exclui os grandes bancos (doravante, "base outros"). Para a base de dados dos bancos pequenos e médios, o modelo foi rodado sem a dummy referente a instituição de grande porte.

De maneira ideal, utilizar-se-ia um modelo com equações simultâneas, abrangendo tanto o lado da oferta quanto 
o da demanda, uma vez que a quantidade cedida deve resultar de um equilíbrio entre oferta e demanda, considerando-se o preço relativo entre as fontes de financiamento tradicionais (depósitos e capital próprio) e cessão de créditos; porém, devido à indisponibilidade de dados dos cessionários e sobre o custo das fontes de financiamento, isso não é possível. Ainda assim, as dummies de tempo devem capturar variações exógenas da demanda por créditos cedidos, que afetariam de maneira homogênea o custo relativo entre as fontes de financiamento para todas as instituições financeiras em cada período. Implícito no modelo, portanto, está o fato de que os choques macroeconômicos (com exceção da crise financeira global) afetam o custo da cessão de maneira uniforme entre os bancos.

Existe a possibilidade de que as variáveis índice de Basileia e liquidez sejam endógenas (não só a cessão afeta diretamente essas medidas como também é possível que o gestor decida simultaneamente sobre seu nível de liquidez, capital e cessão - o que é mitigado, mas não completamente tratado, pelo uso de variáveis defasadas). Dessa forma, alternativamente, utiliza-se um modelo em que essas variáveis são instrumentalizadas. Os instrumentos utilizados foram as próprias variáveis defasadas em dois períodos.

Embora o nível de depósitos também pudesse ser considerado, em tese, endógeno à cessão, Oliveira et al., (2012) mostram que a quantidade de depósitos dos bancos brasileiros não responde às taxas de juros pagas nos certificados de depósitos e que a variação de depósitos durante a crise financeira foi causada por uma mudança exógena na percepção de risco sobre os bancos brasileiros, o que reforça a característica exógena dos depósitos, consistente com o modelo de Kashyap, Rajan, e Stein (2002). Ainda assim, utiliza-se a variável de maneira defasada para mitigar preocupações quanto a sua possível endogeneidade.

Finalmente, para mitigar preocupações relativas à endogeneidade das variáveis, utiliza-se como teste de robustez a estimação usando um modelo dinâmico, o método dos momentos generalizados (GMM-Sys), proposto por Blundell \& Bond (1998), em que todas as variáveis são consideradas potencialmente endógenas, com exceção das dummies de tempo e da dummy para banco de grande porte. Mesmo que esse modelo seja menos apropriado em virtude da característica limitada à esquerda da variável dependente, ele tem o propósito de tratar problemas de endogeneidade, que poderiam não ser completamente tratadas pelo uso de variáveis instrumentais, e correlação entre os termos de erro e as variáveis independentes, que poderia gerar estimadores inconsistentes na regressão em Tobit com efeitos aleatórios.

\section{RESULTADOS}

Os resultados das estimações em Tobit em painel, com e sem variáveis instrumentais, e a estimação em GMM-Sys são mostrados nas Tabelas 3 (base total) e 4 (base outros). Também foram rodadas regressões com os dados em pooled Tobit e em GMM-Sys, incluindo as observações em que não houve cessão por dois períodos subsequentes (não reportados); os resultados são qualitativamente inalterados. Todas as regressões utilizam erros padrão robustos à heterocedasticidade. De maneira geral, os resultados são consistentes entre os diversos tipos de estimação. Nas regressões em GMM-Sys, os coeficientes apresentam maior significância estatística, mas os erros padrão podem estar subestimados devido ao problema de variável dependente limitada à esquerda. Dessa forma, deve-se ter pouca confiança em sua significância estatística.

Os resultados das Tabelas 3 e 4 mostram que não foi encontrada relação estatisticamente significante entre a dummy de crise (sem interação) e cessão de crédito, embora o sinal obtido para a variável tenha sido positivo em quase todas as especificações. Esse resultado mostra que a crise não teve efeito uniforme entre todos os bancos na cessão de crédito. Conforme apresentado a seguir, a crise impactou de maneira distinta a cessão entre bancos com grande parcela de seu financiamento por meio de depósitos.

Verifica-se que bancos com maior restrição de capital próprio (menor índice de Basileia) cedem mais, em especial na modalidade sem coobrigação, o que confirma a Hipótese 1. A cessão sem coobrigação, ao contrário da cessão com coobrigação, libera capital regulatório em definitivo. Esse resultado é consistente com a hipótese H1.a de que bancos fazem cessão sem coobrigação para "liberar" capital. Essa relação é estatisticamente significante tanto para a amostra que contém todos os bancos (Tabela 3) quanto para aquela que exclui os grandes bancos (Tabela 4), em todas as especificações, exceto na regressão em GMM-Sys para a amostra que exclui grandes bancos (ainda assim, o coeficiente é negativo e tem a mesma ordem de grandeza que nas outras especificações). Essa relação é também economicamente significante: para a amostra total, a redução de um ponto percentual no índice de Basileia implica um aumento de cerca de 0,5 a o, 8 ponto percentual (dependendo da especificação) na variável cessão sem coobrigação/crédito total, para a amostra que contém todos os bancos, e efeito similar naquela que exclui os bancos de grande porte. A interação entre o índice de Basileia e a dummy de crise, entretanto, mostrou-se não significante em todas as especificações, o que indica que os efeitos da restrição de capital próprio sobre a cessão não se exacerbam durante a crise. 
TABELA 3. Resultados do painel com efeitos aleatórios rodados para a base total

\begin{tabular}{|c|c|c|c|c|c|c|c|c|c|c|}
\hline & & $\begin{array}{l}\text { Tobit Ef. } \\
\text { Aleatórios }\end{array}$ & IV Tobit & GMM-Sys & $\begin{array}{l}\text { Tobit Ef. } \\
\text { Aleatórios }\end{array}$ & IV Tobit & GMM-Sys & $\begin{array}{l}\text { Tobit Ef. } \\
\text { Aleatórios }\end{array}$ & IV Tobit & GMM-Sys \\
\hline $\begin{array}{l}\text { Dummy de } \\
\text { crise }\end{array}$ & & 1,291 & 1,239 & $0,780^{* *}$ & 1,005 & 0,783 & 0,341 & 0,215 & 0,551 & 0,421 \\
\hline \multirow[t]{2}{*}{ Basileia } & L/IV & $-0,557$ & $-0,476$ & $-0,463^{\star \star *}$ & $-0,619$ & $-0,477$ & $-0,412^{\star \star \star}$ & $-0,509^{\star *}$ & $-0,792^{\star \star \star}$ & $-0,514^{\star *}$ \\
\hline & & $(0,102)$ & $(0,253)$ & $(0,000)$ & $(0,163)$ & $(0,358)$ & $(0,000)$ & $(0,012)$ & $(0,004)$ & $(0,040)$ \\
\hline \multirow[t]{2}{*}{$\begin{array}{l}\text { Depósitos/ } \\
\text { ativos }\end{array}$} & L & $-0,253$ & 0,019 & $-0,207^{*}$ & 0,063 & 0,191 & 0,139 & $-0,363^{\star *}$ & $-0,264$ & $-0,066$ \\
\hline & & $(0,383)$ & $(0,955)$ & $(0,073)$ & $(0,854)$ & $(0,622)$ & $(0,172)$ & $(0,037)$ & $(0,215)$ & $(0,239)$ \\
\hline $\begin{array}{l}\text { D_crise. } \\
\text { dep/at }\end{array}$ & & $(0,116)$ & $(0,098)$ & $(0,064)$ & $(0,409)$ & $(0,518)$ & $(0,405)$ & $(0,160)$ & $(0,048)$ & $(0,024)$ \\
\hline \multicolumn{11}{|l|}{$\begin{array}{l}\text { Variáveis de } \\
\text { controle }\end{array}$} \\
\hline \multicolumn{2}{|c|}{ Var. dependente defasada } & & & $0,928^{\star \star \star}$ & & & $0,964^{\star \star \star}$ & & & $0,827^{\star \star *}$ \\
\hline & & & & $(0.000)$ & & & $(0,000)$ & & & $(0,000)$ \\
\hline \multirow[t]{2}{*}{$\begin{array}{l}\text { Dummy } \\
\text { grandes }\end{array}$} & & 0,269 & $-0,020$ & 0,044 & $-0,656$ & $-0,653$ & 0,098 & 0,116 & 0,090 & 0,105 \\
\hline & & $(0,659)$ & $(0,974)$ & $(0,841)$ & $(0,455)$ & $(0,428)$ & $(0,608)$ & $(0,710)$ & $(0,789)$ & $(0,299)$ \\
\hline tamanho & $\mathrm{L}$ & 0,002 & 0,003 & $-0,088^{\star \star}$ & $-0,020$ & $-0,008$ & $-0,046^{\star *}$ & $-0,019$ & $-0,043$ & $-0,036^{* *}$ \\
\hline $\begin{array}{l}\text { D_crise. } \\
\text { tamanho }\end{array}$ & & $(0,183)$ & $(0,231)$ & $(0,049)$ & $(0,360)$ & $(0,413)$ & $(0,339)$ & $(0,956)$ & $(0,775)$ & $(0,012)$ \\
\hline \multirow[t]{2}{*}{$\begin{array}{l}\text { D_crise. } \\
\text { liquidez }\end{array}$} & L/IV & 0,000 & $-0,000$ & 0,000 & $-0,000$ & 0,000 & 0,000 & $-0,000$ & $-0,000$ & 0,000 \\
\hline & & $(0,554)$ & $(0,914)$ & $(0,863)$ & $(0,915)$ & $(0,982)$ & $(0,711)$ & $(0,627)$ & $(0,245)$ & $(0,771)$ \\
\hline $\begin{array}{l}\text { Dummies de } \\
\text { tempo }\end{array}$ & & SIM & SIM & SIM & SIM & SIM & SIM & SIM & SIM & SIM \\
\hline $\begin{array}{l}\text { Núm. } \\
\text { observações }\end{array}$ & & 1047 & 799 & 1032 & 1047 & 799 & 1032 & 1047 & 799 & 773 \\
\hline $\begin{array}{l}\text { Log } \\
\text { likelihood }\end{array}$ & & $-437,610$ & $-364,834$ & - & $-372,659$ & $-315,467$ & - & $-139,208$ & $-132,436$ & - \\
\hline Prob > chi2 & & $<0,001$ & $<0,001$ & $<0,001$ & $<0,001$ & $<0,001$ & $<0,001$ & 0,037 & 0,191 & $<0,001$ \\
\hline Wald stat. & & 103,500 & 51,690 & 1775,33 & 101,190 & 55,530 & 1961,18 & 31,340 & 21,840 & 307,65 \\
\hline Sargan & & - & - & 373,75 & - & - & 304,12 & - & - & 257,51 \\
\hline $\begin{array}{l}\text { Sargan } \\
\text { (p-value) }\end{array}$ & & - & - & $<0,001$ & - & - & $<0,001$ & - & - & $<0,001$ \\
\hline
\end{tabular}

Nota: A primeira coluna refere-se às variáveis incluídas no modelo; a presença do “L” indica que a variável é defasada e “IV", variável instrumental (nas regressões IV Tobit). Todas as regressões incluem dummies de tempo. Os números entre parênteses abaixo dos coeficientes referem-se aos p-valores, calculados com base em errospadrão robustos à heterocedasticidade. Nas regressões em GMM-Sys, permite-se que os regressores sejam sequencialmente exógenos, adotando variáveis defasadas como instrumentos, exceto para a variável de grande banco e as dummies de tempo Os testes de Sargan são feitos com base em erros-padrão não robustos. ***, ** e * indicam significância ao nível de 1\%,5\% e 10\%, respectivamente. 
TABELA 4. Resultados do painel com efeitos aleatórios rodados para a base excluindo os grandes bancos

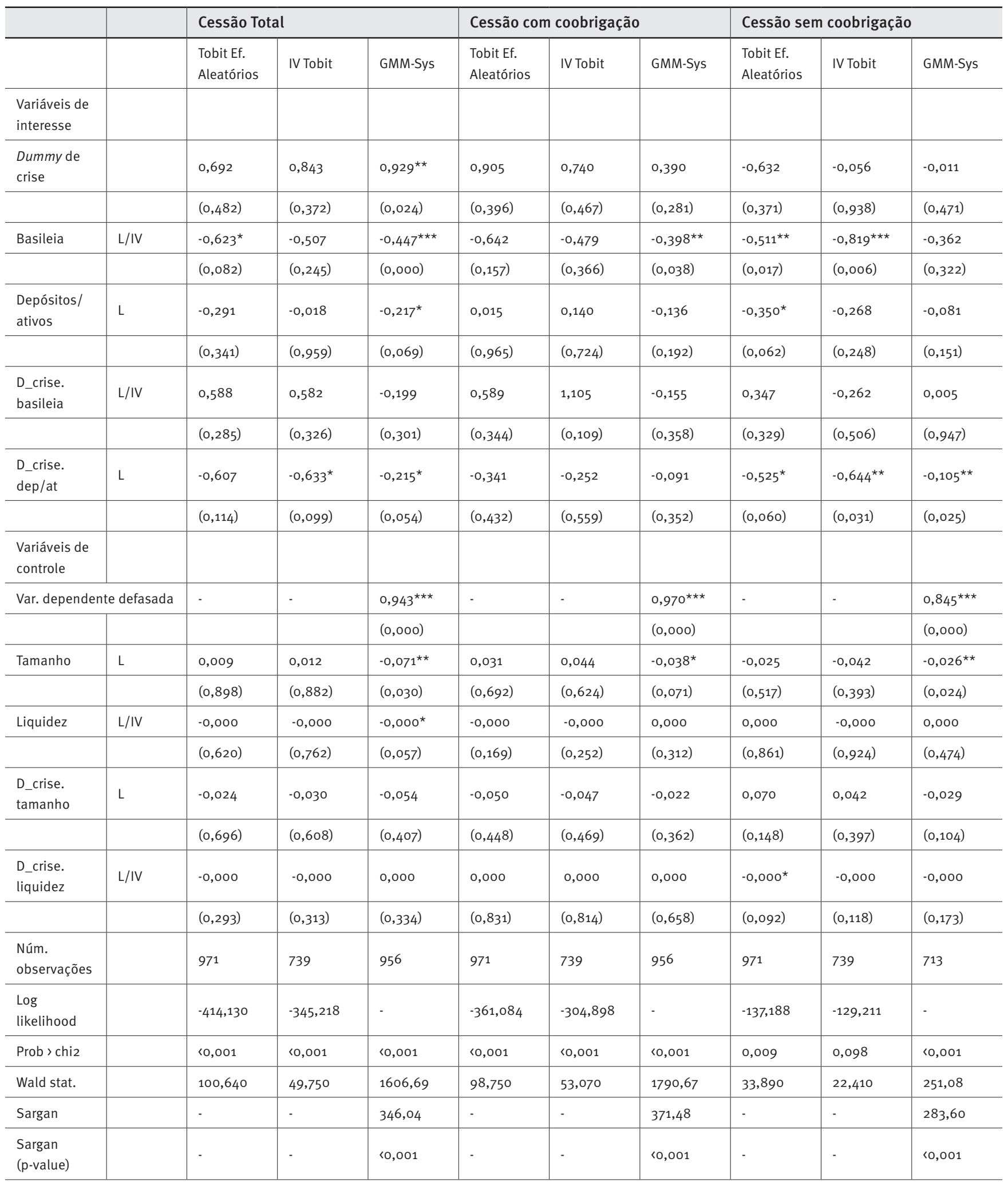

Nota: A primeira coluna refere-se às variáveis incluídas no modelo; a presença do "L” indica que a variável é defasada e "IV”, variável instrumental (nas regressões IV Tobit). Todas as regressões incluem dummies de tempo. Os números entre parênteses abaixo dos coeficientes referem-se aos p-valores, calculados com base em errospadrão robustos à heterocedasticidade. Nas regressões em GMM-Sys, permite-se que os regressores sejam sequencialmente exógenos, adotando variáveis defasadas

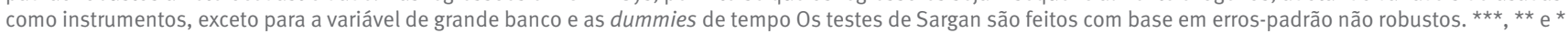
indicam significância ao nível de 1\%,5\% e 10\%, respectivamente. 
Quanto à variável que mede a restrição de capital de terceiros (depósitos/ativos), os resultados mostram uma evidência, ainda que bastante fraca (significância de $10 \%$ e em algumas especificações), de que, no período como um todo, há uma relação negativa entre a proporção dos ativos financiados por depósitos e a cessão sem coobrigação. Durante a crise, no entanto, a queda no financiamento com depósitos parece ser um determinante importante da cessão de crédito, especialmente na modalidade sem coobrigação. Os resultados são ainda mais fortes (estatística e economicamente) para a amostra de bancos pequenos e médios: uma redução de um ponto percentual na razão depósitos/ativos aumenta a razão cessão sem coobrigação/crédito total em cerca de 0,5 a 0,6 ponto percentual durante a crise nas especificações em Tobit. Na especificação em GMM-Sys, o efeito estimado é menor, mas, ainda assim, é estatisticamente significante. Dessa forma, confirma-se também a Hipótese 2.

Esse último resultado é também consistente com a ideia de que, em tempos normais, cessão de crédito e depósitos possam ser enxergados como fontes complementares de financiamento, ao lado dos empréstimos interbancários. Durante a crise, no entanto, houve uma fuga de depósitos dos bancos pequenos e médios para os bancos de grande porte (Oliveira et al., 2012), aliada a uma quase paralisação do mercado interbancário. Nesse contexto, os resultados indicam que os bancos que perderam depósitos recorreram à cessão de crédito como fonte substituta de financiamento durante a crise.

É provável que esse aumento de cessão por parte dos bancos que mais perderam depósitos durante a crise possa ser, pelo menos em parte, explicado pelas medidas adotadas pelo BACEN para estimular a compra de carteiras de bancos pequenos por parte dos grandes bancos. Durante a crise, o BACEN permitiu a liberação de depósitos compulsórios dos grandes bancos para a compra de carteiras de crédito de bancos de menor porte, reduzindo o custo de oportunidade para a compra de carteiras. É intrigante, no entanto, que o aumento de cessões tenha se dado principalmente na modalidade sem coobrigação. Num ambiente de crise, em que o principal impacto nos bancos não foi sobre seu capital regulatório, mas, sim, sobre o financiamento por meio de depósitos, e a assimetria de informação sobre os empréstimos cedidos é maior, esperar-se-ia que o cessionário demandasse que o cedente retivesse parte do risco da carteira cedida (ou seja, que a cessão fosse feita na modalidade com coobrigação), de modo a mitigar os problemas de risco moral. É possível que os bancos que compraram carteiras durante a crise tenham demandado apenas carteiras de empréstimos de boa qualidade e com menor nível de assimetria de informação.
Em relação às variáveis de controle relativas ao porte da instituição, não se encontrou relação estatisticamente significante nos modelos Tobit. Já em algumas das especificações em GMM-Sys, o tamanho apresenta sinal negativo e significativo. Considerando que os erros padrão no modelo GMM-Sys podem estar subestimados, no entanto, a evidência não é suficiente para afirmar que o tamanho dos bancos é determinante para a decisão do volume cedido, seja o efeito contínuo medido pela variável tamnho (logaritmo natural dos ativos totais) ou o efeito descontínuo medido pela dummy de bancos grandes, seja durante a crise ou fora dela. Uma possível explicação para a diferença entre os resultados da estimação em GMM-Sys e Tobit em painel seria que o efeito aleatório específico estivesse correlacionado com a variável de tamanho nas especificações Tobit. Também poderia ser especulado que o efeito do tamanho estivesse capturado no componente de efeitos aleatórios. Na regressão com os dados em pooled Tobit (não reportada), em que os efeitos aleatórios são suprimidos, os resultados, no entanto, também não mostram significância para as variáveis de tamanho.

Finalmente, não se verificou relação entre a liquidez dos bancos e o nível de cessão de crédito. Na variável que captura o efeito da liquidez sobre a cessão durante a crise, apenas em algumas das especificações a variável é estatisticamente significante, e, ainda assim, a significância econômica é muito baixa (os coeficientes apresentam zeros até a sétima casa decimal). Esse resultado também é, até certo ponto, surpreendente, uma vez que a cessão de crédito é, em tese, uma maneira rápida de recomposição da liquidez. Em especial durante a crise, em que muitos bancos sofreram perdas de depósitos, poder-se-ia imaginar que estes tenham reduzido seu nível de liquidez para fazer frente aos saques. Uma possível explicação para o fato de não se encontrar relação entre liquidez e cessão é que a administração da liquidez seja feita no curtíssimo prazo, de maneira que a defasagem de um semestre seja muito longa para que se possa capturar qualquer efeito dessa natureza.

\section{Testes de robustez}

Em adição aos testes realizados e reportados acima, foram realizados diversos testes de robustez (não reportados).

Considerando a base contendo todas as instituições, foi aplicado o critério de exclusão das instituições que possuíssem crédito/ativo inferior a 5\% e 15\% (em lugar dos 10\% adotados inicialmente), para o modelo Tobit em painel com efeitos aleatórios. As inferências sobre a relação entre restrição de capital e cessão de crédito não sofreram alteração com essas modificações. 
Para averiguar os problemas do estimador GMM-Sys na condição de variável inferiormente limitada a zero, estima-se o modelo GMM-Sys excluindo-se as observações em que o valor observado de cessão total é zero em dois períodos subsequentes. Embora essa amostra exclua cerca de 2/3 das observações e contenha um viés de seleção, os sinais das variáveis de interesse e da maioria das variáveis de controle não são alterados. Obviamente, os coeficientes são distintos dos obtidos na regressão que não exclui essas observações.

Os demais testes de robustez foram rodados também com o modelo Tobit em painel e considerando a mesma amostra usada para os testes reportados na seção anterior. Primeiro, foram adicionadas, uma por vez, as variáveis ROE, capital aberto, depósito interbancário e a interação entre índice de Basileia e depósito sobre ativos, definidas na segunda seção. Mais uma vez, os coeficientes das variáveis Basileia e depósito/ativo e suas interações com a dummy de crise são apenas marginalmente alterados, não mudando as inferências principais. Destaca-se que a interação tripla Basileia $x$ depósito sobre ativos $x$ crise apresentou sinal negativo e significante para a cessão sem coobrigação, indicando que a restrição conjunta de capital próprio e de terceiros durante a crise tem um efeito sobre a cessão. Os depósitos interbancários, entretanto, apresentaram efeito inexpressivo.

Segundo, substituiu-se a variável Basileia pelas dummies referentes ao buffer de capital (buffer alto e buffer baixo), com as respectivas interações com a dummy de crise. Embora os sinais obtidos sejam todos consistentes com os resultados das especificações-base - isto é, a dummy de buffer alto tem o mesmo sinal de Basileia e a dummy de buffer baixo, o sinal contrário - apenas uma das variáveis (buffer alto x crise) é significante em uma das especificações (cessão sem coobrigação), ao passo que todas as demais são não significantes. Embora os resultados sejam robustos à definição de restrição do capital próprio, o índice de Basileia, por si só, parece, assim, medir melhor essa restrição do que as dummies construídas com base nele.

Finalmente, testou-se, com um modelo Logit em painel com efeitos aleatórios, a decisão de fazer ou não cessão de crédito (em qualquer modalidade). Nesse teste, a variável dependente passa a ser uma dummy que assume valor 1 se o banco fez qualquer tipo de cessão num dado período e zero, caso contrário, e as variáveis independentes são as mesmas do modelo-base. Alguns dos resultados desse teste, de maneira geral, também são consistentes com os reportados nas Tabelas 3 e 4 . Bancos com maior índice de Basileia têm menores chances de ceder, e o efeito marginal da crise, isto é, o coeficiente resultante da interação Basileia x crise, é nulo. Não se encontra, no entanto, relação entre os depósitos e a decisão de fazer cessão, seja na crise ou no período como um todo. Finalmente, identifica-se que os grandes bancos têm maiores chances de fazer cessão (relação estatisticamente significante a menos de 1\%). Esse resultado não é surpreendente, uma vez que, dado o nível de complexidade das atividades desses bancos, é esperado que façam algum tipo de cessão. Em especial, esses bancos fazem crédito imobiliário, que é tipicamente de longo prazo e, comumente, cedido a Fundos de Investimento em Direitos Creditórios (FIDCs). Embora esses grandes bancos não façam mais cessão que os demais (em proporção ao tamanho da carteira de crédito), eles comumente têm, assim, alguma atividade de cessão em quase todos os períodos.

\section{CONCLUSÃO}

Este estudo buscou verificar se há relação positiva entre restrição de capital e as operações de cessão de crédito realizadas pelos bancos brasileiros. Por se tratar de estudo seminal no assunto, buscou-se também traçar um panorama geral desse mercado no Brasil e descrever os normativos que disciplinam a cessão de crédito no País e suas implicações para as hipóteses testadas. 0 período analisado incluiu o impacto da recente crise financeira, acontecimento relevante tendo em vista a dificuldade enfrentada pelas instituições financeiras diante da redução dos depósitos livres e interbancários.

Os resultados mostram que há forte evidência sobre a existência de relação positiva entre restrição de capital e as operações de cessão de crédito nos bancos brasileiros. Em especial, durante a crise financeira, a restrição de capital de terceiros (depósitos) parece ter sido um determinante importante das cessões, particularmente na modalidade sem coobrigação. Considerando-se que durante a crise iniciada em setembro de 2008 - um evento que pode ser considerado exógeno ao sistema bancário brasileiro - houve uma fuga de depósitos dos bancos pequenos e médios, a relação negativa encontrada entre depósitos e cessão durante esse período (tanto na amostra completa quanto na amostra que contém apenas os bancos de pequeno e médio portes) indica que a cessão de crédito possa servir como um substituto dos depósitos no financiamento dos bancos. É bastante plausível, ainda, que as medidas adotadas pelo BACEN para incentivar a compra de carteiras de bancos menores pelos maiores durante a crise tenham tido papel importante para a observação desse resultado.

A evidência anterior mostra que as consequências da crise global para o sistema financeiro nacional se deram muito mais nos depósitos e muito menos no capital regulatório dos bancos, ao contrário do que se observou em mercados desen- 
volvidos, em que a capitalização dos bancos se deteriorou em virtude das perdas com inadimplência. Os resultados aqui apresentados reforçam essa evidência, mostrando que, embora a restrição de capital próprio seja o principal determinante para a cessão de créditos em tempos normais, a cessão de créditos apareceu como fonte substituta aos depósitos perdidos pelos bancos de pequeno e médio portes durante a crise. Isso é consistente, portanto, com um cenário em que, durante a crise, dois efeitos importantes são verificados: i) uma redução exógena na captação em depósitos dos bancos pequenos e médios, possivelmente ocasionada pela mudança na percepção de risco dos depositantes; ii) um aumento exógeno na demanda por cessão, possivelmente causado pelas medidas do BACEN para incentivar a compra de carteiras pelos grandes bancos. Em outras palavras, a crise alterou exogenamente a relação entre os custos de cessão e depósitos, que, de acordo com o modelo de Pennacchi (1988), é um dos determinantes fundamentais da cessão de créditos.

Como limitações do estudo, vale ressaltar que, por ausência de dados, não foi possível analisar as características dos créditos cedidos (tipo de empréstimos, qualidade e prazo das carteiras, e assim por diante). A consideração dessas características permitiria não apenas traçar uma mapa mais preciso do mercado de cessão, identificando quais tipos de empréstimos são cedidos, mas também identificar determinantes diferentes para cada tipo de empréstimo e traçar uma relação mais estreita entre cessão e restrição de capital. Em especial, seria bastante desejável compreender a diferença entre cessão de créditos de boa e má qualidade (como créditos em atraso e cuja inadimplência já tenha sido refletida nos resultados financeiros do banco).

Além disso, é importante que se estude, como já mencionado, o lado da demanda por cessões, pois, em períodos agudos, como os de crise, a demanda pode influenciar significativamente o que e quanto será cedido. Em especial, deve haver determinantes distintos para a cessão feita a FIDCs, que, muitas vezes, podem ser administrados pelo próprio conglomerado cedente, ou a outras instituições financeiras.

Por fim, sugere-se, também, que estudos futuros incorporem a análise do impacto da vigência da Resolução $n$. 3.533/2008 (desde janeiro de 2012) sobre o mercado de cessões no País, uma vez que os bancos precisarão assumir o risco da carteira e as consequências da exigência de maior alocação de capital. Adicionalmente, as próprias instituições financeiras estão buscando alternativas para obter maior controle sobre tais operações e a diminuição do risco de fraudes. Entre elas, está a criação da Central de Cessão de Crédito (C 3 ), no final de 2011, que registra dados de compra e venda de carteira, como data, prazo e taxas das carteiras de crédito. Dessa forma, caso o originador do crédito conceda desconto ou renegociação, o cessionário estará ciente, havendo maior controle sobre o mercado secundário.

\section{NOTA DOS AUTORES}

As opiniões expressas neste trabalho são exclusivamente dos autores e não refletem, necessariamente, a visão do Banco Central do Brasil.

\section{REFERÊNCIAS}

Affinito, M, \& Tagliaferri, E. (2010). Why do (or did?) banks securitize their loans? Evidence from Italy. Journal of Financial Stability, 6(4), 189202.

Aït-Sahalia, Y, Andritzky, J, Jobst, A, Nowak, S, \& Tamirisa, N. (2012). Market response to policy initiatives during the global financial crisis. Journal of International Economics, 87(1), 162-177.

Banco Central do Brasil. (2008, dezembro). Relatório de inflação. Recuperado em 4 abril, 2011, de http://www.bcb.gov.br/htms/relinf/ port $/ 2008 / 12 /$ ri200812P.pdf

Blundell, R, \& Bond, S. (1998). Initial conditions and moment restrictions in dynamic panel data models. Journal of Econometrics, $87(1)$, 115143 .

Cabiles, N. A. S. (2011). Hedging illiquidity risk through securitization: evidence from loan commitments. Proceedings of the Annual Meeting of the Midwest Finance Association, Chicago, Illinois, 60.

Cantor, R, \& Demsetz, R. (1993). Securitization, loan sales and the credit slowdown. Federal Reserve Bank of New York Quarterly Review, 18(2), 27-37.

Carlstrom, C, \& Samolyk, K. (1995). Loan sales as a response to market-based capital constraints. Journal of Banking and Finance, 19(3-4), 627-646.

Conselho Monetário Nacional. (2008). Resolução 3.533/2008. Recuperado em 10 abril, 2011, de https://www3.bcb.gov.br/normativo/detalharNormativo.do?method=detalharNormativo $\& N=108010163$.

Diamond, D. W, \& Dybvig, P. H. (1983). Bank runs, deposit insurance, and liquidity. The Journal of Political Economy, 91(3), 401-419.

Farruggio, C, Michalak, T, \& Uhde, A. (2011). Share price response to credit risk securitization in European banking. Proceedings of the Southwest Finance Association Annual Meeting, Houston, 50.

Fernandez, F. R, Valverde, S. C, \& Rosen, R. (2011). Securitization, lending and financial stability: evidence from covered bonds and mortgage-backed securities. Proceedings of the Annual Meeting of the Midwest Finance Association, Chicago, Illinois, 60.

Gorton, G. B, \& Pennacchi, G. G. (1995). Banks and loan sales: marketing nonmarketable assets. Journal of Monetary Economics, 35(3), 389-411.

Greenbaum, S. I, \& Thakor, A.V. (1987). Bank funding modes, securitization versus deposits. Journal of Banking and Finance, 11(3), 379-401. 
Kashyap, A, Rajan, R, \& Stein, J. (2002). Banks as liquidity providers: an explanation for the coexistence of lending and deposit-taking. Journal of Finance, 57(1), 33-73.

Loutskina, E. (2011). The role of securitization in bank liquidity and funding management. Journal of Financial Economics, 100(3), 663-684.

Martín-Oliver, A, \& Saurina, J. (2007). Why do banks securitize their assets? Banco de España. Recuperado em 6 abril, 2011, de http://www. finance-innovation.org/risko8/files/3433996.pdf.

Oliveira, G. C. (2009). O comportamento do crédito e a reação do Banco Central e do sistema financeiro público e privado aos efeitos da crise internacional. Anais do Encontro Internacional da Associação Keynesiana Brasileira, Porto Alegre, 2. Recuperado em 2 abril, 2011, de http://www. ppge.ufrgs.br/akb/encontros/2009/49.pdf.

Oliveira, R. F., Schiozer, R. F.; Barros \& L. A. B. C. (no prelo). Depositors perception of "Too big to fail". Review of Finance.
Parlour, C, \& Plantin, G. (2008). Loan sales and relationship banking. Journal of Finance, 63(3), 1291-1314.

Panetta, F, \& Pozzolo, A. F. (2009). Why do banks securitize their assets? Bank-level evidence from over one hundred countries. Proceedings of the International "Tor Vergata" Conference on Banking and Finance, Rome, 18.

Pennacchi, G. G. (1988). Loan sales and the cost of bank capital. Journal of Finance, 43(2), 375-396.

Pereira, J. A. C. M, \& Saito, R. (2012). How do capital buffers respond to basel? An empirical analysis of the Brazilian banking system. Proceedings of the Midwest Finance Association Annual Meeting, New Orleans, Louisiana, 61.

Schiozer, R, Oliveira, R. F, \& Saito, R. (2010). Why do banks go public? Evidence from the 2005-2007 wave of Brazilian bank IPOs. Banks and Bank Systems, 5(2), 96-107. 